\title{
Prevalence and factors associated with incidents related to medication in surgical patients
}

\author{
PREVALÊNCIA E FATORES ASSOCIADOS AOS INCIDENTES RELACIONADOS À \\ MEDICAÇÃO EM PACIENTES CIRÚRGICOS
}

\section{PREVALENCIA Y FACTORES ASOCIADOS CON LOS INCIDENTES RELACIONADOS A LA MEDICACIÓN EN PACIENTES QUIRÚRGICOS}

\section{Thatianny Tanferri de Brito Paranaguá ${ }^{1}$, Ana Lúcia Queiroz Bezerra ${ }^{2}$, Andressa Luanna Moreira dos Santos ${ }^{3}$, Ana Elisa Bauer de Camargo Silva ${ }^{4}$}

\begin{abstract}
The aim of this study was to estimate the prevalence and factors associated with the occurrence of incidents related to medication, registered in the medical records of patients admitted to a Surgical Clinic, in 2010. This is a cross-sectional study, conducted at a university hospital, with a sample of 735 hospitalizations. Was performed the categorization of types of incidents, multivariate analysis of regression logistic and calculated the prevalence. The prevalence of drug-related incidents was estimated at $48.0 \%$ and were identified, as factors related to the occurrence of these incidents: length of hospitalization more than four days, prescribed three or more medications per day and realization of surgery intervention. It is expected to have contributed for the professionals and area managers can identify risky situations and rethink their actions.
\end{abstract}

\section{RESUMO}

Estudo de corte transversal, conduzido em um hospital universitário, com amostra de 735 internações, cujo objetivo foi estimar a prevalência e os fatores associados à ocorrência de incidentes relacionados à medicação, registrados em prontuários de pacientes internados em uma clínica cirúrgica no ano de 2010. Foi realizada a categorização dos tipos de incidentes com apresentação das frequências absoluta e relativa, calculada a prevalência e realizada análise multivariada. A prevalência dos incidentes relacionados à medicação foi estimada em $48,0 \%$ e identificaram-se como fatores relacionados a sua ocorrência o tempo de internação igual ou superior a quatro dias, a prescrição de três ou mais medicamentos por dia e a realização de intervenção cirúrgica. Espera-se ter contribuído para que os profissionais e gestores da área possam identificar situações de risco e repensar sua atuação.

\author{
DESCRITORES \\ Erros de medicação \\ Segurança do paciente \\ Enfermagem \\ Gestão em saúde
}

\section{RESUMEN}

Estudio de corte transversal, realizado en un Hospital docente, con una muestra de 735 internaciones, cuyo objetivo fue estimar la prevalencia y los factores asociados a la ocurrencia de incidentes relacionados a la medicación, registrados en las historias clínicas de los pacientes hospitalizados en el Servicio de Cirugía, en el año de 2010. Se realizó la categorización de los tipos de incidentes y fueron presentados la frecuencia absoluta y relativa, calculando la prevalencia y realizando el análisis multivariante. La prevalencia de los incidentes relacionados a la medicación se estimó en $48,0 \%$ y fueron identificados como factores relacionados a la ocurrencia de estos incidentes: tiempo de la hospitalización igual o superior a cuatro días, prescripción de tres o más medicamentos por día y realización de la intervención quirúrgica. Se espera haber contribuido para que los profesionales y administradores del área puedan identificar situaciones de riesgo y revisar su actuación.

DESCRIPTORES
Errores de medicación
Seguridad del paciente
Enfermería
Gestión en salud

${ }^{1}$ Master in Nursing, Faculty of Nursing, Federal University of Goias, Goiania, Go, Brazil. ttb.paranagua@gmail.com ${ }^{2}$ PhD. Associate Professor, Faculty of Nursing, Federal University of Goias. ${ }^{3}$ Undergraduate Nursing, Faculty of Nursing, Federal University of Goias. ${ }^{4}$ PhD. Full Professor, Faculty of Nursing, Federal University of Goias. 


\section{INTRODUCTION}

Currently, drug therapy has been widely used and more than $80 \%$ of individuals who seek health services are prescribed medications ${ }^{(1)}$. However, improper use and lack of safety standard during the administration of the drug can lead to serious incidents to patients ${ }^{(2)}$.

The World Health Organization (WHO) defines incidents as events or circumstances that may or may not cause harm to the patient ${ }^{(3)}$. Among the incidents related to medication we highlight the adverse effect and medication error, being the latter incident, an avoidable one ${ }^{(4)}$.

It is estimated that at least $\mathbf{1 . 5}$ million people in the U.S. are affected every year by medication errors, which leads to costs higher than 3.5 billion dollars to the health care system $^{(5)}$. These rates are even more relevant in the context of surgical care, as 234 million surgeries are estimated to occur per year. The World Health Organization considers the perioperative administration of drugs complex, since the 11,000 medication errors in the perioperative registered in the United States, 5\% resulted in damage to patients including death ${ }^{(5)}$.

However, it is very difficult to estimate the real extent of the damage attributable to medication errors in the perioperative period, as there is a possibility of underreporting of the consequences to the patient due to fear of punishment. Given the high rate of surgical procedures performed annually worldwide, it is believed that there is a substantial amount of patients affected by incidents related to drug interventions. It is estimated that hospitals spend on average $15-20 \%$ of their budgets to reverse complications caused by misuse of medicines ${ }^{(5-6)}$.

The risks associated with this therapy may be minimized by investing in the quality of prescribing and dispensing of medicines and integration of specialized knowledge and complementary expertise among professionals who prescribe and dispense those drugs, which allows the achievement of efficient and beneficial results to patients ${ }^{(2)}$.

This study seeks to contribute to the knowledge of the incidents that occur during the medication process, raising the professionals involved reflections on their care practices to adopt attitudes that promote a culture of safety. Furthermore, this study will present factors associated with the occurrence of incidents related to medication factors, currently considered a limited thematic in the scientific community.

Thus, this research aims to estimate the prevalence and factors associated with the occurrence of incidents related to medication registered from medical records of patients admitted to the surgical clinic of a teaching hospital.

\section{METHOD}

Cross-sectional and retrospective study, conducted at the surgical clinic of a teaching hospital in the Sentinel
Hospital Network of the National Health Surveillance Agency. The hospital has a Risk Management sector and supports research to diagnose incidents, in order to develop educational activities and promote the culture of safety, a fact that motivated the development of this research at the institution.

The population included all patients admitted to the surgical clinic of the hospital during the year 2010, totaling 2,610 hospitalizations. The calculated sample size was 735 patients, whereas the prevalence of incidents of $10 \%$ estimated by $\mathrm{WHO}^{(7)}$, the statistical power of $95 \%$, accuracy of $3 \%$, a design effect of 2.0 and an increase of $10 \%$ due to possible losses during data collection. We used a probabilistic and systematic sampling.

Medical records of patients with hospital admission date from January 1st to December 31st 2010 were included. We considered only the incidents recorded in the prescription papers and clinical evolution, laboratory or imaging tests were not consulted.

The outcome variable was the incident related to medication. The independent variables were related to the patient (age, gender, comorbidities) and hospitalization (admission type, length of hospitalization, surgery, amount of medications prescribed/per day, catheters, daily clinical assessment of patient).

Data were collected between January and May of 2011. We used a structured questionnaire, reviewed by experts who are professors in the area of administration, who also develop researches on the topic. After suggested reformulations, a pilot-test was conducted through a retrospective analysis of 45 medical records, which were randomly selected in order to solve possible logistical and execution issues. Data obtained during the pilot-test were not used in this research. The final form used for data collection consisted of objective questions on the hospitalization characteristics and a table containing a place for notes for information about the incident.

Data were entered into a database built using the software Statistical Package for the Social Sciences, version 17.0 for Windows. The categorization of the types of incidents was conducted, the prevalence of the incident and their confidence intervals were calculated. Descriptive data analysis was performed and to identify factors associated with incident factors in univariate analysis, we used the chi-square and Fisher's exact test, when necessary, with the odds ratio (OR) as a measure of association. Multivariate logistic regression analysis was performed with gender, age, and with $p<0.10$ in the univariate analysis. Confidence intervals of $95 \%$ were calculated and associations that had $p$-value $<0.05$ were considered statistically significant.

The study complied with national and international standards of ethics in human research and was approved by the ethics committee of the institution (Protocol No. 064 /2008).
Prevalence and factors associated with incidents related to medication in surgical patients Paranaguá TTB, Bezerra ALQ, Santos ALM, Silva AEBC 


\section{RESULTS}

We analyzed 735 hospitalizations, which corresponds to $28.1 \%$ of patients admitted to the surgical clinic of the hospital in 2010, as shown in Table 1.

Table 1 - Characterization of patients admitted to the surgical clinic of a teaching hospital in 2010 - Goiania, GO, 2013

\begin{tabular}{|c|c|c|}
\hline VARIABLE & $\mathbf{N}$ & $\%$ \\
\hline \multicolumn{3}{|l|}{ Gender } \\
\hline Male & 295 & 40.1 \\
\hline Female & 440 & 59.9 \\
\hline \multicolumn{3}{|l|}{ Age } \\
\hline 0 to 14 years & 38 & 5.1 \\
\hline 15 to 59 years & 493 & 67.1 \\
\hline 60 years old or more & 204 & 27.8 \\
\hline \multicolumn{3}{|l|}{ Comorbidities } \\
\hline Yes & 310 & 42.2 \\
\hline No & 405 & 55.1 \\
\hline Lack of information & 20 & 2.7 \\
\hline \multicolumn{3}{|l|}{ Type of admission } \\
\hline Urgency & 129 & 17.6 \\
\hline Elective & 606 & 82.4 \\
\hline \multicolumn{3}{|l|}{ Medical expertise } \\
\hline General surgery & 137 & 18.6 \\
\hline Urology & 101 & 13.7 \\
\hline Gynecology & 97 & 13.2 \\
\hline Otorhinolaringology & 95 & 12.9 \\
\hline Proctology & 82 & 11.2 \\
\hline Vascular surgery & 75 & 10.2 \\
\hline Mastology & 54 & 7.3 \\
\hline Maxillofacial & 26 & 3.5 \\
\hline Cardiac surgery & 23 & 3.2 \\
\hline Neurology & 20 & 2.7 \\
\hline Other & 25 & 3.5 \\
\hline \multicolumn{3}{|l|}{ Length of hospitalization } \\
\hline 1-3 days & 406 & 55.2 \\
\hline 4-97 days & 329 & 44.8 \\
\hline \multicolumn{3}{|l|}{ Number of prescribed drugs } \\
\hline Up to 2 drugs per day & 410 & 55.8 \\
\hline 3 or more drugs per day & 325 & 44.2 \\
\hline Total & 735 & 100 \\
\hline
\end{tabular}

There was a predominance of female patients (59.9\%), aged between 15 and 59 years old (67.1\%) with a median of 47 years. In $55.1 \%$ of admissions, patients had comorbidities and in $2.7 \%$ this information was absent, indicating problems in performing anamnesis, which can compromise the quality of care provided to patients. The most frequent type of admission (82.4\%) were elective hospitalization, being predominant specialties of General Surgery (18.6\%), Urology (13.7\%) and Gynecology (13.2\%). The length of hospitalization in $55.2 \%$ of patients was from one to three days, with a median of three days. The number of prescribed drugs was two per day for $55.8 \%$ of hospitalizations, ranging from 1 to 14 , with a mean of 2.6 drugs/day.
In 353 hospitalization, there was exposure to at least one kind of incident related to medication, a prevalence was estimated of $48.0 \%$ (353/735; $\mathrm{Cl}: 44.4$ to 51.6). The types of incidents related to medication from medical records and hospitalized patients who were exposed to each incident are presented in Table 2.

Table 2 - Incidents related to medication that occurred during hospitalization in the surgical clinic of a teaching hospital in 2010 - Goiania, GO, 2013

\begin{tabular}{lcc}
\hline \multirow{2}{*}{ INCIDENTS } & HOSPITALIZATIONS \\
\hline Omission of dose & N & \% \\
Absence of checking medications & 254 & 34.6 \\
Lack of medicine & 215 & 29.3 \\
Discontinuation of drugs & 70 & 9.5 \\
Adverse effect to drugs & 57 & 7.8 \\
Incorrect prescription of medicines & 23 & 3.1 \\
Medication administered at the wrong time & 15 & 2.0 \\
Dose administration of not prescribed drug & 5 & 1.1 \\
Administration of different drug from & 2 & 0.7 \\
prescribed & & 0.3 \\
Administration of medication in the wrong & 1 & \\
patient & & 0.1 \\
Administration of medication in the wrong & 1 & 0.1 \\
place & & \\
\hline
\end{tabular}

The most frequent incident was the omission of dose, observed in $34.6 \%$ hospitalizations. The absence of checking medications occurred in $29.3 \%$ and lack of medicine in the unit was recorded at least once in $9.5 \%$ of hospitalizations. Another incident identified in $7.8 \%$ hospitalizations was the discontinuation of drugs, which may indicate flaws in prescribing or management the unit, related to forecasting and the provision of medicines to meet the needs of hospitalized patients.

Although in small proportions, it was also verified the occurrence of other incidents in the medication process as adverse effects (3.1\%), incorrect prescription $(2.0 \%)$, wrong time $(1.1 \%)$, dose administration of not prescribed drugs $(0.7 \%)$, administration of medication in the wrong patient $(0.1 \%)$, and administration of medication in the wrong place $(0.1 \%)$, which points to systemic failures. No data on the consequences of incidents for patients were found.

As shown in Table 3, the incident related to the medication has a multifactorial characteristic.

Univariate analysis showed factors associated with the occurrence of incidents related to medication in people who: were over 45 years old, had a length of hospitalization greater than or equal to four days, urgency hospitalization, had comorbidities, number of medications prescribed per day greater than or equal to three and performed surgical intervention. The independent variables for the occurrence of incidents related to medication can be seen in Table 4. 
Table 3 - Univariate association between exposure variables and the occurrence of incidents related to medication in patients admitted to the Surgical Clinic of the University Hospital in 2010 - Goiania, GO, 2013

\begin{tabular}{|c|c|c|c|c|c|}
\hline \multirow{2}{*}{$\begin{array}{l}\text { EXPOSURE } \\
\text { VARIABLES }\end{array}$} & \multicolumn{2}{|c|}{ INCIDENT } & \multirow[b]{2}{*}{ OR } & \multirow[b]{2}{*}{$95 \% \mathrm{CI}$} & \multirow[b]{2}{*}{$\mathbf{p}$} \\
\hline & $\begin{array}{c}\text { Exposure/ } \\
\text { Total }\end{array}$ & $\%$ & & & \\
\hline \multicolumn{6}{|l|}{ Gender } \\
\hline Male & $143 / 295$ & 48.5 & 1.09 & $0.82-1.48$ & 0.534 \\
\hline Female & $203 / 440$ & 46.1 & & & \\
\hline \multicolumn{6}{|l|}{ Age } \\
\hline $\begin{array}{l}45 \text { years old or } \\
\text { more }\end{array}$ & $228 / 391$ & 36.6 & 2.45 & $1.82-3.30$ & 0 \\
\hline Up to 45 years old & $125 / 344$ & 58.3 & & & \\
\hline \multicolumn{6}{|l|}{ Comorbidities } \\
\hline Yes & $186 / 310$ & 60 & 2.48 & $1.84-3.35$ & 0 \\
\hline No & $160 / 425$ & 37.6 & & & \\
\hline \multicolumn{6}{|l|}{ Type of admission } \\
\hline Urgency & $73 / 129$ & 56.6 & 1.59 & $1.08-2.33$ & 0.017 \\
\hline Elective & $273 / 606$ & 45 & & & \\
\hline \multicolumn{6}{|c|}{ Length of hospitalization } \\
\hline Four or more days & $247 / 329$ & 75.1 & 9.34 & $6.67-13.09$ & 0 \\
\hline One to three days & $99 / 406$ & 24.4 & & & \\
\hline \multicolumn{6}{|c|}{ Medicines prescribed per day } \\
\hline Three or more & $226 / 325$ & 69.5 & 5.52 & $4.01-7.58$ & 0 \\
\hline Up to two per day & $120 / 410$ & 29.2 & & & \\
\hline \multicolumn{6}{|l|}{ Surgical intervention } \\
\hline Yes & $275 / 634$ & 43.4 & 0.32 & $0.21-0.51$ & 0 \\
\hline No & $71 / 101$ & 70.3 & & & \\
\hline \multicolumn{6}{|l|}{ Catheter Use } \\
\hline Yes & $312 / 673$ & 46.3 & 0.71 & $0.42-1.20$ & 0.201 \\
\hline No & $34 / 62$ & 54.8 & & & \\
\hline \multicolumn{6}{|c|}{ Daily evolution of the patient's condition } \\
\hline Yes & $247 / 522$ & 47.3 & 0.97 & $0.70-1.33$ & 0.836 \\
\hline No & $99 / 213$ & 46.5 & & & \\
\hline
\end{tabular}

A relationship was observed between the occurrence of incidents involving drugs and length of hospitalization less than four days, the prescription of three or more medications per day and performance of any surgical interventions.

The length of hospitalization greater than four days $(p=0.000)$ showed a risk of incident 6.12 times greater than the length of hospitalization up to three days and $75.1 \%$ of hospitalizations over four days were exposed to a drug-related incident versus $24.4 \%$ exposure among hospitalizations with up to three days.

The prescription of three or more medications per day $(p=0.000)$ contributed to the occurrence of incidents related to medication, increasing the risk by 3.32 times. Among hospitalizations with three or more medication prescriptions per day, $69.5 \%$ were exposed to an incident while hospitalized people with up to two medications prescriptions per day, exposure was $29.2 \%$ (Table 4 ).

The performance of surgical interventions $(p=0.041)$ also indicated a risk factor for the occurrence of incidents related to medication, increasing chances in 1.78 times. Although $70.3 \%$ of hospitalizations for surgical intervention have been exposed to an incident, the number of exposure among patients who did not undergo surgery was higher.

\section{DISCUSSION}

The characterization of patients at the surgical clinic resembles other studies, especially regarding the predominance of female patients, and young adults ${ }^{(8-9)}$. Most patients had no comorbidities and elective admissions predominated, which is a characteristic in this type of hospital, unlike the results of studies in which the focus was the urgent and emergency care ${ }^{(9)}$.

In $55.8 \%$ of hospitalizations two medications were prescribed per day, ranging from 1 to 14 and a mean of 2.6/ day. The need to use multiple drugs can be attributed to the treatment of comorbidities or complications incurred during hospitalization, related to the clinical status of the patient or the surgical procedure.

Table 4 - Risk factors and their odds ratio values for the occurrence of incidents related to medication during hospitalization in the surgical clinic of a teaching hospital in 2010 - Goiania, GO, 2013

\begin{tabular}{lccc}
\hline \multicolumn{1}{c}{ Risk Factors } & Not adjusted & \multicolumn{2}{c}{ ODDS RATIO (95\% CI) } \\
& p & pdjusted & 0.661 \\
\hline Male gender & $1.09(0.82-1.48)$ & 0 & $0.92(0.64-1.32)$ \\
Age $>$ 45 years old & $2.45(1.82-3.30)$ & 0 & $1.31(0.90-1.92)$ \\
Presence of comorbities & $2.48(1.84-3.35)$ & 0 & $0.94(0.63-1.39)$ \\
Urgency admission & $1.59(1.08-2.33)$ & 0.017 & $1.39(0.85-2.27)$ \\
Hospitalization $>$ 4 days & $9.34(6.67-13.09)$ & 0 & $6.12(4.23-8.84)$ \\
Medicines $>$ 3 per day & $5.51(4.01-7.58)$ & 0 & $3.32(2.27-4.85)$ \\
Performance of surgical intervention & $0.32(0.21-0.51)$ & 0 & 0.193 \\
\hline
\end{tabular}


The characteristics of patients and hospitalizations of this study are specific and point to the need for individualized care planning. It is extremely important to characterize the profile of patients, therefore, the greater the severity and complexity of care required, the greater the chance of errors that compromise the quality of care ${ }^{(10)}$.

The prevalence of incidents related to medication was $48.0 \%$. The medication error incident is the third most frequent arising from care. Retrospective studies have shown that their occurrence varies from 14.8 to $51.5 \%$ of reported events in large teaching hospitals ${ }^{(11-12)}$. The prevalence of these incidents in an observational study that evaluated the process of administration of antimicrobials was approximately $30.2 \%{ }^{(13)}$. The difference between the values found may be related to the possibility of underreporting, since different sources of information and hospital culture may influence whether or not the record of the incident is documented.

Among the types of incidents, the omission of dose was more frequent. Prospective studies indicate that 14.0 to $28.0 \%$ of the records of drug incidents are due to omission of dose $\mathrm{e}^{(14-15)}$. In retrospective studies, this rate reached $51.0 \%{ }^{(16)}$. Studies conducted with health professionals indicate that up to $71.0 \%$ have detected incidents due to omission of dose ${ }^{(17)}$.

The absence of checking and lack of medicines suggest flaws in the organization of the service and the care process. National and international, prospective and retrospective studies, identified those same occurrences as faults during patient care, both in surgical environments as in other hospital units ${ }^{(18-19)}$.

Retrospective analysis of adverse effects notification in outpatients and hospitalized patients in a public hospital in northeastern Brazil showed that $72.0 \%$ of patients had an adverse effect and $15.0 \%$, more than one. The occurrence of these events in hospitalized patients accounted for $54.1 \%$ of all notifications and only $1.5 \%$ was reported by the surgical clinic $^{(8)}$.

Although in this study the incidents of administration of medicine in the wrong time, not prescribed dose, medication not prescribed, wrong patient, and wrong place have been recorded to a lesser proportion, the literature contains several studies that describe the high rate of these incidents ${ }^{(14,16,20-21)}$.

Prospective, observational study in a French teaching hospital found that in $27.6 \%$ of cases observed occurred at least one error in the medication process. The time errors accounted for $72.6 \%$ of the incidents and administration of unauthorized medicine product, administration in the wrong patient or non-prescribed drugs occurred in $3.7 \%{ }^{(14)}$.

The time errors are the second most common incident, corresponding to $22.9 \%$ of the events, and rate of $13.5 \%{ }^{(16,21)}$. Are also identified, although to a lesser extent, errors in prescribing $(4.1 \%)$, omission of dose $(4.1 \%)$ and medication administered at the wrong patient $(2.7 \%)^{(21)}$.

The nursing staff, while not responsible for the prescription, need to know the aspects involved in each step of the process because, when acting in the stages of preparation and administration, enables them to intercept errors that went unnoticed ${ }^{(10,22-23)}$. About $86 \%$ of medication errors can be intercepted by nurses and pharmacists and updating of knowledge is a strong ally in prevention ${ }^{(1,24)}$.

Prolonged hospitalization time, the use of multiple medications and surgical intervention constituted a risk factor for the occurrence of drug incidents. A retrospective analysis showed that the probability of surviving free from incidents related to medication administration during hospitalization process is inversely proportional to the amount of time patient remain hospitalized. For 30, 60 and 100 days of hospitalization, the probability of not suffering incident with medication was 96,93 and $73 \%$, respectively ${ }^{(10)}$. It is noteworthy, therefore, the importance of knowing the influence of the factor time in the occurrence of different outcomes.

The extension of hospitalization may be due to a complication caused by error of the healthcare team ${ }^{(25)}$. Prolonged hospitalization period may be associated with anticipation of hospitalization or postponement of discharge for assurance of hospitalization, cancellation and rescheduling of surgery or need for exams. The prolongation of hospital stay also increases the likelihood of adverse events, whereas there is the patient's exposure to risk factors intrinsic to the hospital environment ${ }^{(10)}$.

Concomitant administration of various drugs in different dosages and presentations, can cause confusion to the professional and trigger an error. Retrospective study of patients hospitalized at the University of Pittsburgh, United States, found that patients receiving intravenous medications have 3\% higher risk of having an adverse event and the risk increases with each drug dispensed ${ }^{(26)}$.

A realização de intervenção cirúrgica também foi identifiThe surgical intervention was also identified as factor associated with the occurrence of incidents related to medication, depending on patient characteristics and type of surgery, and the preparation of appropriate preoperative care and skill and qualification of the surgeon ${ }^{(25)}$. The most common postoperative complications are decreased cardiac output, renal failure, cardiac arrest, arrhythmia, pneumonia, hyperglycemia, heart failure and cerebrovascular accident ${ }^{(27)}$. Knowing the possible postoperatively complications assists the healthcare team to adopt a rapid response to reverse the worsening condition of the patient.

The study from the University of Pittsburgh found that patients with kidney injury, thrombocytopenia and those admitted emergently were, respectively, 16 , three and two times higher probability of a related medication incident ${ }^{(26)}$. 
Retrospective analysis of general care in health institutions in England found between the risk factors associated with drug incidents, male under 15 years or over 64 years and the number of single doses prescribed ${ }^{(28)}$.

The risks associated with surgical procedures require the creation of new interventions for clinical stabilization, including additional drug therapies, providing new risk situations, if the patient is not well monitored and properly assistance planning.

We observe, therefore, that the incidents related to medication administration are common and mild to moderate harm are more frequent ${ }^{(28)}$. However, when the patient's condition is critical, drug incidents are 2.9 times more likely to result in harm requiring intervention to support life, and 2.5 times more likely to result in permanent harm or death ${ }^{(15)}$.

Strategies to reduce these incidents should focus on staff training, the continued development of professionals, clinical leadership and improved patient's communication and security systems ${ }^{(24,28)}$.

Resolution No.36 of the National Health Surveillance Agency has required the installation of the Center for Patient Safety in health institutions. Notification of incidents arising out of care may contribute to production, systematization and dissemination of knowledge about the incidents, and fostering a culture of safety in training and practice of health ${ }^{(29)}$.

The disclosure of accurate concepts about the types of incidents and understanding that are mainly caused by inadequacies in work processes is a challenge and

\section{REFERENCES}

1. Lopes DMA, Néri EDR, Madeira LS, Souza Neto PJ, Lélis ARA, Souza TR, et al. Análise da rotulagem de medicamentos semeIhantes: potenciais erros de medicação. Rev Assoc Med Bras. 2012;58(1):95-103.

2. Pepe VLE, Castro CGSO. A interação entre prescritores, dispensadores e pacientes: informação compartilhada como possível benefício terapêutico. Cad Saúde Pública [Internet]. 2000 [citado 2013 fev. 22];16(3):815-22. Disponível em: http://www.scielosp.org/pdf/csp/v16n3/2966.pdf

3. World Health Organization. Conceptual framework for the International Classification for Patient Safety. Version 1.1 [Internet]. Geneva; 2009 [cited 2013 Feb 22]. Available from: http://www.who.int/patientsafety/implementation/taxonomy/ icps_technical_report_en.pdf at the same time, a need to direct the improvement of patient care $^{(30)}$.

\section{CONCLUSION}

The prevalence of incidents related to medication was $48.0 \%$, highlighting the omission of dose, the absence of checking, lack of medication, discontinuation of medication, adverse effects and incorrect prescription. As factors associated to the occurrence of incidents we highlight the length of hospitalization greater than or equal to four days, the prescription of three or more medications per day and any surgical intervention. The identification of these factors associated is a unique contribution of this study and it may support the adoption of specific strategies that minimize the chances of occurrence of the incident related to medication at risk population.

The results can be generalized and methodology of this study can be used to investigate these incidents in other health units in order to estimate the actual extent of drug incidents in Brazil, as well as encourage the pursuit of appropriate preventive measures to the reality of our country.

The lack of policy development of the health care professionals team for the notification of incidents difficult their monitoring and is a present problem in the health sector with several implications for the quality of care.

The study has limitations in the method of retrospective analysis, since the record of the incident and especially the harm to the patient depends on the attitude of health professionals, moreover, influenced by the organizational culture of the institution where he/she works for.

4. Capucho HC. Near miss: almost error or potential event? [letter to the editor]. Rev Latino Am Enferm [Internet]. 2011 [citado 2013 Feb 22];19(5):1272-3. Available from: http://www. scielo.br/pdf/rlae/v19n5/27.pdf

5. World Health Organization. Word Alliance for Patient Safety. Guidelines for safe surgery: safe surgery saves lives [Internet]. Geneva; 2009 [cited 2013 Feb 22]. Available from: http://whqlibdoc.who.int/publications/2009/9789241598552_eng.pdf

6. World Health Organization. Global partnerships for health. WHO Drug Inf. 1999;13(2):61-4.

7. World Health Organization. Word alliance for patientt safety: forward program 2006-2007 [Internet]. Geneva; 2007 [cited 2010 Jan 20]. Available from: http://www.who.int/patientsafety/information_centre/WHO_EIP_HDS_PSP_2006.1.pdf

8. Toledo LAK, Noblat L, Noblat ACB, Noblat MG, Oliveira PMS. Adverse drug reactions at a university hospital in Brazil. Rev $\mathrm{Ci}$ Med Biol. 2010;9(1):40-5.

Prevalence and factors associated with incidents related to medication in surgical patients Paranaguá TTB, Bezerra ALQ, Santos ALM, Silva AEBC 
9. Martins M, Travassos C, Mendes W, Pavão AL. Hospital deaths and adverse events in Brazil. BMC Health Serv Res. 2011;11:223.

10. Roque KE, Melo ECP. Tempo de internação e a ocorrência de eventos adversos a medicamentos: uma questão da enfermagem. Esc Anna Nery Rev Enferm. 2011;15(3):595-601.

11. Lima LF, Leventhal LC, Fernandes MPP. Identificando os riscos do paciente hospitalizado. Einstein. 2008;6(4):434-8.

12. 12. Nascimento CCP, Toffoletto MC, Gonçalves LA, Freitas WG, Padilha KG. Indicators of healthcare results: analysis of adverse events during hospital stays. Rev Latino Am Enferm. 2008;16(4):746-51.

13. Marques TC, Reis AMM, Silva AEBC, Gimenes FRE, Opitz SP, Teixeira TCA, et al. Erros de administração de antimicrobianos identificados em estudo multicêntrico brasileiro. Rev Bras Ciênc Farm. 2008;44(2):305-14

14. Berdot S, Sabatier B, Gillaizeau F, Caruba T, Prognon P, Durieux $P$. Evaluation of drug administration errors in a teaching hospital. BMC Health Serv Res. 2012;12:60.

15. Latif A, Rawat N, Pustavoitau A, Pronovost PJ, Pham JC. National study on the distribution, causes, and consequences of voluntarily reported medication errors between the ICU and Non-ICU settings. Crit Car Med. 2013;41(2):389-98.

16. Silva AEBC, Reis AMM, Miasso Al, Santos JO, Cassiani SH. Adverse drug events in a sentinel hospital in the State of Goiás, Brazil. Rev Latino Am Enferm [Internet]. 2011 [cited 2013 May 15];19(2):378-86. Available from: http://www.scielo. $\mathrm{br} / \mathrm{pdf} / \mathrm{rlae} / \mathrm{v} 19 \mathrm{n} 2 / \mathrm{pt} \_21 . p d f$

17. Franco JN, Ribeiro G, D'Innocenzo M, Barros BPA. Percepção da equipe de enfermagem sobre fatores causais de erros na administração de medicamentos. Rev Bras Enferm. 2010;63(6):927-32.

18. Forster AJ, Asmis TR, Clark HD, Al Saied G, Code CC, Caughey SC, et al. Ottawa Hospital Patient Safety Study: incidence and timing of adverse events in patients admitted to a Canadian teaching hospital. CMAJ. 2004;170(8):1235-40.

19. Setz VG, D'Innocenzo M. Evaluation of the quality of nursing documentation though the review of patient medical records. Acta Paul Enferm [Internet]. 2009 [cited 2013 May 15]; 22 (3): 313-7. Available from: http://www.scielo.br/pdf/ ape/v22n3/a12v22n3.pdf

20. Gimenes FRE, Teixeira TCA, Silva AEBC, Opitz SP, Mota LMS, Cassiani SHB. Influencia da redação da prescrição médica na administração de medicamentos em horários diferentes do prescrito. Acta Paul Enferm. 2009;22(4):380-4.
21. Teixeira TCA, Cassiani SHB. Root cause analysis: evaluation of medication errors at a university hospital. Rev Esc Enferm USP [Internet]. 2010 [cited 2013 May 15];44 (1):137-44. Available from: http://www.scielo.br/pdf/reeusp/v44n1/ en_a20v44n1.pdf

22. Oliveira RB, Melo ECP. O sistema de medicação em um Hospital Especializado no município do Rio de Janeiro. Esc Anna Nery Rev Enferm. 2011;15(3):480-9.

23. Miasso Al, Cassiani SHB. Erros na administração de medicamentos: divulgação de conhecimentos e identificação do paciente como aspectos relevantes. Rev Esc Enferm USP. 2000;34(1):16-25.

24. Silva AEBC, Cassiani SHB, Miasso Al, Opitz SP. Problemas na comunicação: uma possível causa de erros de medicação. Acta Paul Enferm. 2007;20(3):272-6.

25. Oliveira LB, Rocha Junior PB, Guimarães NM, Didonet MT. Variáveis relacionadas ao tempo de internação e complicações no pós-operatório de pacientes submetidos à cirurgia do trato gastrointestinal. Com Ciênc Saúde. 2010;21(4):319-30.

26. Kane-Gill SL, Kirisci L, Verrico MM, Rothschild JM. Analysis of risk factors for adverse drug events in critically ill patients. Crit Care Med. 2012;40(3):823-8.

27. Carvalho MRM, Silva NAS, Oliveira GMM, Klein CH. Complicações e tempo de internação na revascularização miocárdica em hospitais públicos no Rio de Janeiro. Rev Bras Ter Intensiva. 2011;23(3):312-20.

28. Avery AA, Barber N, Ghaleb M, Franklin BD, Armstrong S, Crowe $S$, et al. Investigating the prevalence and causes of prescribing errors in general practice: the PRACtICe study [Internet]. 2012 [cited 2013 Sept 15]. Available from: http:// www.gmc-uk.org/Investigating_the_prevalence_and_ causes_of_prescribing_errors_in_general_practice__ The PRACtICe_study_Reoprt_May_2012_48605085.pdf

29. Brasil. Ministério da Saúde; Agência Nacional de Vigilância Sanitária. Resolução RDC n. 36, de 25 de julho de 2013. Institui ações para a segurança do paciente em Serviços de Saúde e dá outras providências [Internet]. Brasília; 2013 [citado 2013 set. 15]. Disponível em: http://bvsms.saude. gov.br/bvs/saudelegis/anvisa/2013/rdc0036_25_07_2013. html

30. Paranaguá TTB, Bezerra ALQ, Silva AEBC, Azevedo Filho FM. Prevalence of no harm incidents and adverse events in a surgical clinic. Acta Paul Enferm [Internet]. 2013 [cited 2013 July 15];26(3):256-62. Available from: http://www.scielo.br/ pdf/ape/v26n3/09.pdf 